\title{
Liver status and outcomes in patients without previous known liver disease receiving anticoagulant therapy for venous thromboembolism
}

\author{
Diego Martínez-Urbistondo ${ }^{1}$ (1) - Rocío G. de la Garza ${ }^{1}$. Paula Villares-Fernández ${ }^{1}$. Carme Font ${ }^{2}$. \\ Sebastian Schellong ${ }^{3}$. Juan José López-Núñez ${ }^{4,5} \cdot$ Aída Gil-Díaz $^{6} \cdot$ María del Carmen Díaz-Pedroche ${ }^{7}$. \\ Jana Hirmerova ${ }^{8} \cdot$ Manuel Monreal $^{4,9} \cdot$ The RIETE Investigators
}

Received: 5 August 2021 / Accepted: 23 September 2021 / Published online: 9 October 2021

(c) Società Italiana di Medicina Interna (SIMI) 2021

\begin{abstract}
The association between elevated liver enzymes or FIB-4 (fibrosis index 4) and outcome in patients with venous thromboembolism (VTE) has not been evaluated. Data from patients in RIETE (Registro Informatizado Enfermedad TromboEmbólica) were used to assess the association between elevated liver enzymes or FIB-4 levels and the rates of major bleeding or death in apparent liver disease-free patients with acute VTE under anticoagulation therapy. A total of 6206 patients with acute VTE and without liver disease were included. Of them, 92 patients had major bleeding and 168 died under anticoagulation therapy. On multivariable analysis, patients with elevated liver enzymes were at increased mortality risk (HR: 1.58; 95\% CI: 1.10-2.28), while those with FIB-4 levels $>2.67$ points were at increased risk for major bleeding (HR: 1.69; $95 \%$ CI: 1.04-2.74). Evaluation of liver enzymes and FIB-4 index at baseline in liver disease-free patients with VTE may provide additional information on the risk for major bleeding or death during anticoagulation.
\end{abstract}

Keywords Non-invasive liver assessment $\cdot$ Clinical VTE $\cdot$ Healthy individuals $\cdot$ Anticoagulation adverse events $\cdot$ VTE risk assessment

Diego Martínez-Urbistondo

dmurbistondo@gmail.com

1 Internal Medicine Department, HM Sanchinarro, HM Hospitales, C/Oña 10, 28050 Madrid, Spain

2 Department of Medical Oncology, Hospital Clínic, Barcelona, Spain

3 Department of Medical Clinic, Municipal Hospital of Dresden Friedrichstad, Dresden, Germany

4 Department of Internal Medicine, Hospital Germans Trias I Pujol, Badalona, Barcelona, Spain

5 Department of Medicine, Universitat Autònoma de Barcelona, Barcelona, Spain

6 Department of Internal Medicine, Hospital Universitario de Gran Canaria Dr. Negrín, Las Palmas, Spain

7 Department of Internal Medicine, Hospital Universitario 12 de Octubre, Madrid, Spain

8 Department of Internal Medicine, University Hospital Plzen, Plzen, Czech Republic

9 Chair for the Study of Thromboembolic Disease, Faculty of Health Sciences, UCAM-Universidad Católica San Antonio de Murcia, Murcia, Spain

\begin{tabular}{|c|c|}
\hline \multicolumn{2}{|c|}{ Abbreviations } \\
\hline FIB-4 & Fibrosis index 4 \\
\hline VTE & Venous thromboembolism \\
\hline RIETE & $\begin{array}{l}\text { Registro informatizado enfermedad } \\
\text { tromboembólica }\end{array}$ \\
\hline CT scan & Computer tomography scan \\
\hline $\mathrm{PE}$ & Pulmonary embolism \\
\hline DVT & Deep vein thrombosis \\
\hline HR & Hazard ratio \\
\hline BMI & Body mass index \\
\hline
\end{tabular}

\section{Introduction}

The evaluation of liver enzymes in patients without liver diseases has become an emerging topic of research, most likely due to progressive aging of the population, increasing use of hepatotoxic drugs and better knowledge of non-alcoholic fatty liver disease [1-3]. Elevated liver enzymes in asymptomatic people has been associated with an increased risk for cardiovascular diseases or death, [4-8] and an increased incidence of venous thromboembolism (VTE) in one study [9]. Moreover, liver fibrosis is an important prognostic factor 
in patients with a number of liver disorders [10-14]. Patients with raised fibrosis 4 index (FIB-4) have a higher incidence of atrial fibrillation, [15] myocardial infarction, [16] diabetes, [17] or coronary artery disease [18]. It also has some prognostic value in patients with sepsis or SARS-CoV-2 $[19,20]$. Interestingly, patients with ischemic stroke and raised FIB-4 levels (but not elevated liver enzymes) were at increased risk for hemorrhagic transformation in one study [21]. However, no studies have consistently evaluated the association between elevated liver enzymes or FIB-4 levels and outcome in patients with acute VTE.

The RIETE ( boEmbólica) registry is an ongoing, international, prospective registry of consecutive patients with objectively confirmed acute venous thromboembolism (VTE). Data from this registry have been used to evaluate outcomes after VTE, such as the frequency of recurrent VTE, major bleeding or mortality, and risk factors for such outcomes [22]. The aim of the current analysis was to assess the association between elevated liver enzymes or FIB-4 levels and outcome in a cohort of apparent liver disease-free patients with acute VTE.

\section{Patients and methods}

\section{Data source}

We used the data from the RIETE registry, which prospectively collects information on consecutive patients with objectively confirmed, acute VTE (ClinicalTrials.gov identifier, NCT02832245). Previous publications have reported the design and conduct of the RIETE registry [22]. All patients (or their relatives) provided written or oral informed consent for participation in the registry, in accordance with the local ethics committee requirements.

\section{Study design}

Information on serum liver enzymes was included into the RIETE database in November 2013. Thus, the study included patients only from November 2013 to July 2020 . We aimed to compare the outcomes appearing during the course of anticoagulation in apparent liver disease-free patients with VTE, according to the presence of: (1) elevated vs. normal liver enzymes in serum; and (2) degree of liver fibrosis, as quantified using the FIB-4 score.

\section{Patients}

Consecutive patients with acute, symptomatic VTE confirmed by objective tests [ventilation-perfusion lung scan, contrast CT scan for pulmonary embolism (PE); compression ultrasonography or contrast venography for deep vein thrombosis (DVT)] were recruited in RIETE. Patients were excluded if they were currently participating in a blind therapeutic clinical trial as reported by the investigator in charge of each patient inclusion in the registry. No SARS-CoV-2-positive patients were included in the present study.

\section{Exclusion criteria}

The exclusion criteria to participate in this study were: presence of active or prior cancer; liver cirrhosis, HIV infection or chronic hepatitis including patients with chronic viral hepatitis, autoimmune hepatitis or genetic liver disease which could lead to confusion in terms of liver status assessment, excessive alcohol consumption considered according to previously validated parameters [23] ( $>3$ standard drinks a day for $>65$-year-old patients and women, $>5$ standard drinks a day for men), VTE diagnosis in patients hospitalized for other reasons, platelet count at baseline of $<100,000 / \mu \mathrm{L}$ or $>1,000,000 / \mu \mathrm{L}$; and aspartate aminotransferase (AST) or alanine aminotransferase (ALT) levels of $<1 \mathrm{UI} / \mathrm{L}$ or $>200$ UI/L obtained in a standardized laboratory (Fig. 1). Clinical characteristics were obtained from the report of cases by each hospital.

\section{Study variables}

The following parameters were recorded in the RIETE registry: demographics, comorbidities, risk factors for VTE, clinical status including any coexisting or underlying conditions such as chronic heart or lung disease, recent $(<30$ days before) major bleeding, anemia or renal insufficiency, treatment received for VTE (drugs, doses and dates) and outcomes during at least the first 3 months. Body mass index (BMI) was only recorded in 4723 patients due to the lack of height data. Elevated liver enzymes were considered when AST or ALT levels were $>40 \mathrm{UI} / \mathrm{L}$. The FIB-4 index was calculated according to the following formula: [24]

$$
F I B-4=\frac{\text { Age }(\text { years }) \times A S T(U I / L)}{\text { Plateletcount }(m m 3) \times \sqrt{A L T(U I / L)}} .
$$

Patients with elevated liver enzymes were classified into 3 subgroups of FIB-4 according to previously validated cutoff values for non-alcoholic steatohepatitis (NASH) as follows: $<1.3$ points for low probability of fibrosis; $1.3-2.67$ points for intermediate probability; and $>2.67$ points for high probability of liver fibrosis [25]. We used these cut-offs because NASH is the most likely cause of elevated FIB-4 levels in our patient population [12,13]. 
Fig. 1 Flow chart of selection of patients for final analysis

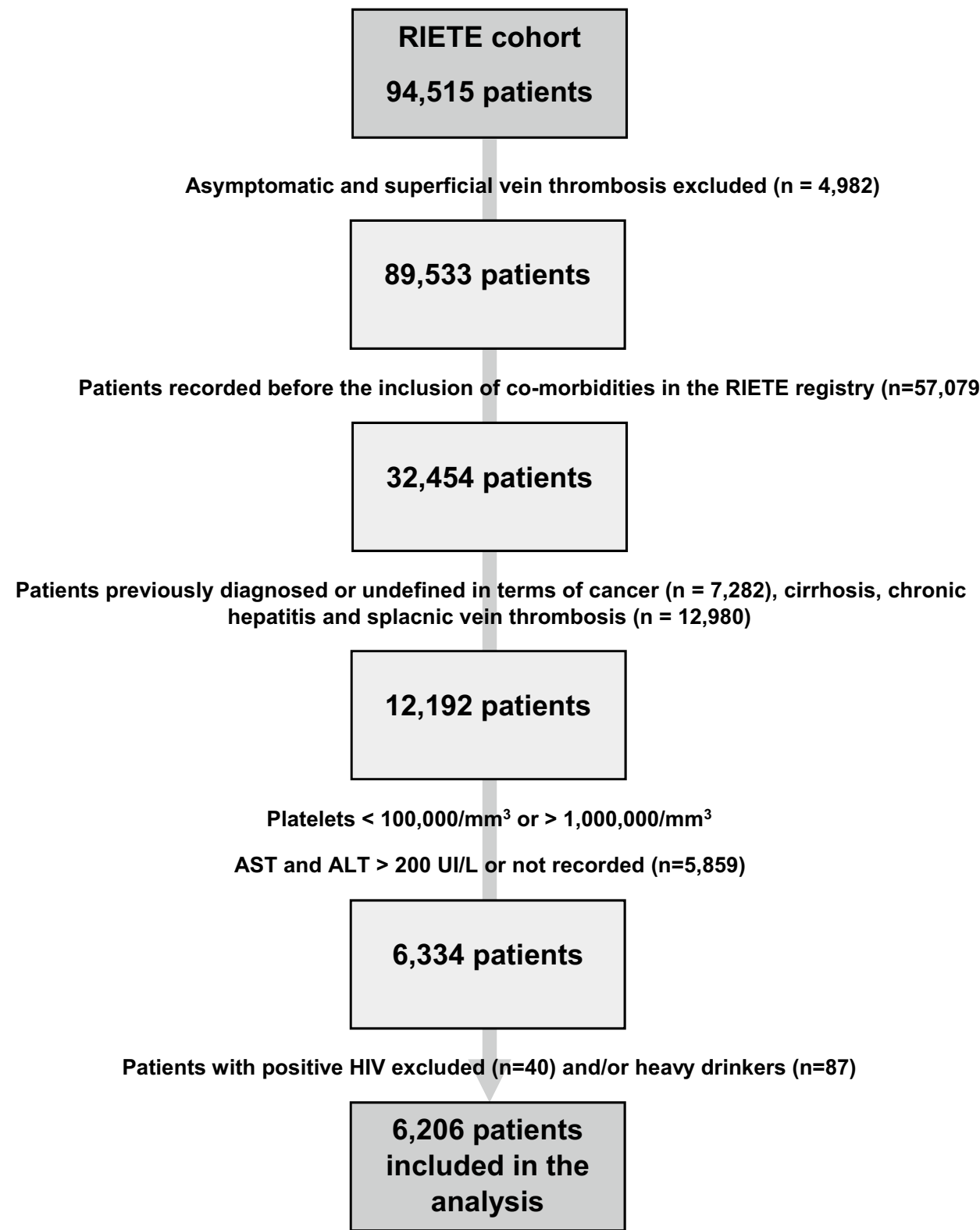

RIETE cohort

94,515 patients

Asymptomatic and superficial vein thrombosis excluded $(n=4,982)$

89,533 patients

32,454 patients

\section{Outcomes}

The major outcomes were the rates of VTE recurrences, major bleeding or all-cause death occurring during the course of anticoagulant therapy. The prognostic ability of elevated liver enzymes, FIB-4 (as a continuous variable) and the 3 mentioned FIB-4 subgroups was evaluated using univariable and multivariable analyses.

\section{Statistical analysis}

Categorical variables were reported as frequency counts (percentages) and compared using the Chi-square test (two sided). Continuous variables were reported as mean and standard error of the mean (or median with inter-quartile range, if not normally distributed), and compared using Student $t$ test. Odds ratios (ORs) and corresponding 95\% confidence intervals (CI) were calculated. The risks for all-cause death or major bleeding according to the presence or absence of elevated serum enzymes or FIB-4 levels were assessed using Cox regression models. For multivariable models, we considered factors previously demonstrated to be prognostically significant or thought to be clinically relevant, and covariates identified in bivariate analyses as predictors of mortality or major bleeding. Covariates included in the adjusted models included: demographics, comorbidities, initial presentation of VTE (PE vs. DVT), risk factors for VTE, baseline laboratory data (including liver enzymes and platelet count) and anticoagulant therapy. Statistically significant 
differences were considered when $p$ value was $<0.05$. All calculations were performed using IBM SPSS Statistics (Chicago, v20.0).

\section{Results}

From November 2013 to July 2020, 6206 patients fulfilled the inclusion and exclusion criteria, and were included into the analyses (Fig. 1). Of these, 4955 (80\%) initially presented with PE (with or without concomitant DVT) and 1251 presented with isolated DVT. Overall, 1275 patients (21\%) had elevated liver enzymes (AST, ALT or both) at baseline; 2721 (44\%) had low probability of fibrosis (FIB-4 levels < 1.3), 2669 (43\%) had intermediate probability (FIB-4 levels 1.3-2.67) and 816 (13\%) had high probability of liver fibrosis (FIB-4 levels $>2.67$ points).

\section{Elevated liver enzymes}

Patients with elevated levels of AST and/or ALT had higher levels of gamma-glutamyl transpeptidase, alkaline phosphatase or FIB-4 than those with normal levels of AST and ALT (Table 1). They were also younger $(61 \pm 18$ vs. $66 \pm 18$ years; $p<0.001$ ), more likely men, more likely presented initially with PE, and more likely had recent surgery or prior stroke, but less likely had anemia or renal insufficiency than patients with normal levels (Table 1). Patients in the elevated liver enzyme group had a statistically significant higher BMI. Among patients initially presenting with PE, those with normal liver enzymes were more likely to have hypotension or tachycardia (Table 2). Most patients with or without elevated liver enzymes (78 vs. $80 \%$ ) received initial therapy with low-molecular-weight heparin (LMWH). Then, half of the patients (49 vs. $45 \%$ ) switched to vitamin $\mathrm{K}$ antagonists (VKAs) and one third (32 vs. 35\%) to direct oral anticoagulants (DOACs).

During the course of anticoagulant therapy [median duration, 4 months; inter-quartile range (IQR), 2-9 months], 66 patients developed VTE recurrences (recurrent PE 43, recurrent DVT 23), 112 suffered major bleeding (in the gastrointestinal tract 38, hematoma 19, intracranial 16) and 168 died. Patients with elevated liver enzymes had a nonsignificantly lower rate of VTE recurrences [hazard ratio (HR): 0.52 ; 95\% CI: 0.25-1.08) and similar rates of major bleeding (HR: 1.13; 95\% CI: 0.70-1.84) or death (HR: 1.10; 95\% CI: 0.77-1.59) than those with normal liver enzymes (Supplementary table I). On multivariable analysis, however, patients with elevated enzymes were at an increased risk for death (HR: 1.58; 95\% CI: 1.10-2.28), but not for major bleeding (HR: 1.39 ; 95\% CI: 0.85-2.27) compared to those with normal levels (Table 3).
Additional models were performed including long-term anticoagulation therapy which demonstrated a higher risk of death in patients with the use of long-term LWMH in comparison to those using vitamin $\mathrm{K}$ antagonist and DOACs, but these results were not included in the final model because they did not modify the prognostic capacity of elevated liver enzymes and to provide an a priori evaluation of mortality risk using only data at baseline. Supplementary analyses were also performed using BMI data. BMI resulted protective in the univariate analysis and was not included in multivariate analysis due to lack of statistical power of the new model, regarding a $31 \%$ of loss of mortality events.

\section{Liver fibrosis}

Patients with high probability of liver fibrosis were much older than those with low probability $(78 \pm 11$ vs. $54 \pm 18$ years; $p<0.001$ ) (Supplementary figure I), more likely presented with PE, and more likely had chronic heart failure, renal insufficiency or recent immobility than those with low probability of fibrosis, but less likely had recent surgery, use of estrogens or recent travel (Table 1). No differences in BMI were found between subgroups. Among patients initially presenting with $\mathrm{PE}$, those with high probability of fibrosis more likely had hypotension or tachycardia at baseline. Patients with intermediate probability of fibrosis were also older than those with low probability $(72 \pm 11$ vs. $54 \pm 18$ years; $p<0.001)$, more likely presented with PE and had recent immobility or renal insufficiency, but less likely had recent surgery, use of estrogens or recent travel (Table 1). There were no differences among subgroups in initial therapy, but patients with high or intermediate probability of fibrosis more likely received long-term therapy with VKAs and less likely with DOACs (Table 2).

During the course of anticoagulation, patients with high probability of liver fibrosis had a higher rate of major bleeding (HR: 1.70; 95\% CI: 1.29-2.24) or all-cause death (HR: 1.86; 95\% CI: $1.51-2.30$ ) than those with low probability of fibrosis, and a similar rate of VTE recurrences (HR: 1.00; 95\% CI: $0.72-1.41$ ). Patients with intermediate probability of fibrosis had a higher mortality rate than those with low probability (HR: 1.84 ; 95\% CI: 1.27-2.67), a lower rate of VTE recurrences (HR: 0.58; 95\% CI: 0.34-0.99) and a similar risk of major bleeding (HR: 1.52; 95\% CI: 0.93-2.48) as shown in supplementary table II. On multivariable analysis, patients with high probability of liver fibrosis were at an increased risk for major bleeding (HR: 1.69; 95\% CI: 1.04-2.74) and at a similar risk for death (HR: $1.23 ; 95 \%$ CI: 0.87-1.75) compared to those with low probability of liver fibrosis (Table 3, Figs. 2, 3). Additional models were carried out, including long-term anticoagulation therapy, which demonstrated an increased risk of bleeding in patients using long-term LMWH compared to those using vitamin K 
Table 1 Clinical characteristics at baseline, according to liver enzymes and FIB-4 levels

\begin{tabular}{|c|c|c|c|c|c|}
\hline & \multicolumn{2}{|l|}{ Liver enzymes } & \multicolumn{3}{|l|}{ FIB-4 levels } \\
\hline & $\begin{array}{l}\text { AST or ALT } \\
>40 \text { IU/L }\end{array}$ & $\begin{array}{l}\text { AST and ALT } \\
\leq 40 \mathrm{IU} / \mathrm{L}\end{array}$ & $>2.67$ & $1.3-2.67$ & $<1.3$ \\
\hline Patients, $N$ & 1275 & 4931 & 816 & 2669 & 2721 \\
\hline \multicolumn{6}{|l|}{ Liver enzymes } \\
\hline AST (mean UI/L $\pm \mathrm{SD}$ ) & $53 \pm 28^{\ddagger}$ & $20 \pm 7$ & $44 \pm 32^{\ddagger}$ & $28 \pm 17^{\ddagger}$ & $21 \pm 12$ \\
\hline ALT (mean UI/L $\pm \mathrm{SD}$ ) & $65 \pm 33^{\ddagger}$ & $19 \pm 8$ & $34 \pm 31^{\dagger}$ & $28 \pm 23$ & $27 \pm 23$ \\
\hline GGT (mean UI/L $\pm \mathrm{SD}$ ) & $98 \pm 110^{\ddagger}$ & $38 \pm 45$ & $59 \pm 73^{\dagger}$ & $50 \pm 64$ & $49 \pm 71$ \\
\hline $\mathrm{AP}($ mean $\mathrm{UI} / \mathrm{L} \pm \mathrm{SD})$ & $101 \pm 60^{\ddagger}$ & $76 \pm 37$ & $88 \pm 49^{\dagger}$ & $81 \pm 44$ & $81 \pm 42$ \\
\hline FIB-4 index $($ mean \pm SD) & $2.11 \pm 1.55^{\ddagger}$ & $1.52 \pm 0.86$ & $3.67 \pm 1.21^{*}$ & $1.84 \pm 0.38^{\ddagger}$ & $0.83 \pm 0.29$ \\
\hline \multicolumn{6}{|l|}{ Demographics } \\
\hline Age (mean years $\pm \mathrm{SD})$ & $61 \pm 18^{\ddagger}$ & $66 \pm 18$ & $78 \pm 11^{\ddagger}$ & $72 \pm 13^{\ddagger}$ & $54 \pm 18$ \\
\hline Male sex & $720(56 \%)^{\ddagger}$ & $2339(47 \%)$ & $390(48 \%)$ & $1321(49 \%)$ & $1348(49 \%)$ \\
\hline Body weight $(\mathrm{kg} \pm \mathrm{SD})$ & $81 \pm 18^{\ddagger}$ & $77 \pm 17$ & $74 \pm 16^{\ddagger}$ & $77 \pm 16^{\dagger}$ & $78 \pm 18$ \\
\hline Body mass index $\left(\mathrm{kg} / \mathrm{m}^{2} \pm \mathrm{SD}\right)$ & $28.8 \pm 5.7^{\ddagger}$ & $28.0 \pm 5.6$ & $28.0 \pm 5.9$ & $28.3 \pm 5.4$ & $28.0 \pm 5.5$ \\
\hline Obese patients $(\mathrm{BMI}>30)$ & $346(35 \%)$ & $1125(30 \%)$ & $172(29 \%)$ & $668(32 \%)$ & $631(31 \%)$ \\
\hline \multicolumn{6}{|l|}{ Initial VTE presentation } \\
\hline Pulmonary embolism & $1060(83 \%)^{\ddagger}$ & $3895(79 \%)$ & $692(85 \%)^{\ddagger}$ & $2211(83 \%)^{\ddagger}$ & $2052(75 \%)$ \\
\hline SBP levels $<100 \mathrm{mmHg}$ & $89(8.4 \%)^{\ddagger}$ & $213(5.5 \%)$ & $69(10 \%)^{\ddagger}$ & $127(5.7 \%)$ & $138(5.1 \%)$ \\
\hline Heart rate $>100 \mathrm{bpm}$ & $274(26 \%)^{\ddagger}$ & $796(20 \%)$ & $194(24 \%)^{\ddagger}$ & $481(18 \%)$ & $474(17 \%)$ \\
\hline \multicolumn{6}{|l|}{ Comorbidities } \\
\hline Diabetes & $196(15 \%)$ & $751(15 \%)$ & $110(14 \%)^{*}$ & $393(15 \%)$ & $444(16 \%)$ \\
\hline Chronic heart failure & $88(6.9 \%)$ & $287(5.8 \%)$ & $61(7.5 \%)^{\ddagger}$ & $162(6.1 \%)$ & $152(5.6 \%)$ \\
\hline Chronic lung disease & $142(11 \%)$ & $556(11 \%)$ & $89(11 \%)$ & $318(12 \%)$ & $291(11 \%)$ \\
\hline $\mathrm{CrCl}$ levels $<30 \mathrm{~mL} / \mathrm{min}$ & $132(10 \%)$ & $575(12 \%)$ & $151(18 \%)^{\ddagger}$ & $348(13 \%)^{*}$ & $208(7.6 \%)$ \\
\hline $\mathrm{CrCl}$ levels $30-60 \mathrm{ml} / \mathrm{min}$ & $383(30 \%)^{\ddagger}$ & $1,842(37 \%)$ & $382(47 \%)^{\ddagger}$ & $1108(41 \%)^{\ddagger}$ & $735(27 \%)$ \\
\hline Prior ischemic stroke & $82(6.4 \%)^{*}$ & $269(5.5 \%)$ & $42(5.1 \%)$ & $142(5.3 \%)$ & $167(6.1 \%)$ \\
\hline No comorbidities & $637(50 \%)$ & $2319(47 \%)$ & $489(60 \%)^{\ddagger}$ & $1549(58 \%)^{\ddagger}$ & $1165(42 \%)$ \\
\hline \multicolumn{6}{|l|}{ Risk factors for VTE } \\
\hline Recent immobility & $324(25 \%)$ & $1190(24 \%)$ & $227(28 \%)^{\ddagger}$ & $676(25 \%)^{\ddagger}$ & $611(22 \%)$ \\
\hline Recent surgery & $129(10 \%)^{*}$ & $412(8.4 \%)$ & $38(4.7 \%)^{\ddagger}$ & $177(6.6 \%)^{\dagger}$ & $326(12 \%)$ \\
\hline Estrogen use & $54(4.3 \%)^{*}$ & $282(5.7 \%)$ & $10(1.2 \%)^{\frac{\xi}{\xi}}$ & $36(1.3 \%)^{\ddagger}$ & $289(11 \%)$ \\
\hline Pregnancy/postpartum & $15(1.2 \%)$ & $74(1.5 \%)$ & $0^{\ddagger}$ & $5(0.2 \%)^{\ddagger}$ & $84(3.1 \%)$ \\
\hline Recent travel & $51(4.0 \%)$ & $164(3.3 \%)$ & $14(1.7 \%)^{\ddagger}$ & $77(2.9 \%)^{\dagger}$ & $124(4.6 \%)$ \\
\hline Unprovoked & $610(48 \%)$ & $2,346(48 \%)$ & $443(54 \%)^{\ddagger}$ & $1381(52 \%)^{\ddagger}$ & $1143(42 \%)$ \\
\hline Prior VTE & $173(14 \%)$ & $795(16 \%)$ & $124(15 \%)$ & $451(17 \%)^{\dagger}$ & $393(14 \%)$ \\
\hline \multicolumn{6}{|l|}{ Bleeding risk } \\
\hline Prior peptic ulcer & $21(1.6 \%)$ & $63(1.3 \%)$ & $14(1.7 \%)$ & $43(1.6 \%)^{*}$ & $27(1.0 \%)$ \\
\hline Recent major bleeding & $28(2.2 \%)$ & $97(2.0 \%)$ & $19(2.3 \%)$ & $46(1.7 \%)$ & $60(2.2 \%)$ \\
\hline Anemia & $291(23 \%)^{\ddagger}$ & $1,357(27 \%)$ & $214(26 \%)$ & $659(25 \%)^{\dagger}$ & $775(28 \%)$ \\
\hline Platelet count $/ 1000 / \mathrm{mm}^{3}$ & $232 \pm 84$ & $234 \pm 82$ & $165 \pm 41^{\ddagger}$ & $209 \pm 53^{\ddagger}$ & $277 \pm 91$ \\
\hline
\end{tabular}

BMI was only recorded in 4723 patients

$A S T$ aspartate aminotransferase, $A L T$ alanine aminotransferase, $I U$ international units, $F I B-4$ Fibrosis liver index 4, $S D$ standard deviation, GGT gamma-glutamyl transferase, $A P$ Alkaline phosphatase, $V T E$ venous thromboembolism, $\mathrm{SBP}$ systolic blood pressure, $\mathrm{CrCl}$ creatinine clearance

Comparisons between patients: ${ }^{*} p<0.05 ;{ }^{\dagger} p<0.01 ;{ }^{\ddagger} p<0.001$ antagonists and DOAC. These results were not included in the final model because they did not modify the prognostic capacity of FIB-4 $>2.67$ and to provide an a priori assessment of the risk of major bleeding using only baseline data.

\section{Discussion}

Data obtained from a large series of apparent liver diseasefree patients with VTE reveal that one in every $5(20 \%)$ of 
Table 2 Treatment strategies

\begin{tabular}{|c|c|c|c|c|c|}
\hline & \multicolumn{2}{|c|}{ Liver enzymes } & \multicolumn{3}{|l|}{ FIB-4 levels } \\
\hline & $\begin{array}{l}\text { AST or ALT } \\
>40 \mathrm{UI} / \mathrm{L}\end{array}$ & $\begin{array}{l}\text { AST and ALT } \\
\leq 40 \mathrm{UI} / \mathrm{L}\end{array}$ & $>2.67$ & $1.3-2.67$ & $<1.3$ \\
\hline Patients, $N$ & 1275 & 4931 & 816 & 2669 & 2721 \\
\hline \multicolumn{6}{|l|}{ Anticoagulation length } \\
\hline Median months (IQR) & $4(2-9)$ & $5(2-10)$ & $4(2-10)$ & $4(2-10)$ & $4(2-9)$ \\
\hline Over 6 months, $n(\%)$ & $451(35 \%)$ & $1,658(34 \%)$ & $288(35 \%)$ & $923(35 \%)$ & $898(33 \%)$ \\
\hline \multicolumn{6}{|l|}{ Initial therapy } \\
\hline LMWH $n(\%)$ & $989(78 \%)$ & $3859(80 \%)$ & $656(80 \%)$ & $2051(77 \%)$ & $2141(79 \%)$ \\
\hline Mean LMWH (IU/kg/day) & $183 \pm 66^{\frac{\ddagger}{\ddagger}}$ & $175 \pm 59$ & $180 \pm 67$ & $176 \pm 60$ & $176 \pm 60$ \\
\hline LMWH < $100 \mathrm{IU} / \mathrm{kg} /$ day & $62(4.9 \%)$ & $308(6.2 \%)$ & $54(6.6 \%)$ & $169(6.3 \%)$ & $147(5.4 \%)$ \\
\hline Unfractionated heparin & $96(7.5 \%)^{\ddagger}$ & $168(3.4 \%)$ & $54(6.6 \%)^{\dagger}$ & $106(4.0 \%)$ & $104(3.8 \%)$ \\
\hline Direct oral anticoagulants & $89(7.0 \%)^{\dagger}$ & $550(11 \%)$ & $44(5.4 \%)^{\ddagger}$ & $313(12 \%)$ & $282(10 \%)$ \\
\hline Others & $60(4.7 \%)$ & $240(4.9 \%)$ & $64(7.8 \%)$ & $199(7.5 \%)$ & $194(7.1 \%)$ \\
\hline Inferior vena cava filter & $32(2.5 \%)$ & $92(1.9 \%)$ & $20(2.5 \%)$ & $51(1.9 \%)$ & $53(1.9 \%)$ \\
\hline \multicolumn{6}{|l|}{ Long-term therapy } \\
\hline Vitamin $\mathrm{K}$ antagonists & $606(49 \%)^{\ddagger}$ & $2223(45 \%)$ & $418(51 \%)^{\ddagger}$ & $1,301(49 \%)^{\ddagger}$ & $1,134(42 \%)$ \\
\hline Direct oral anticoagulants & $404(32 \%)^{\ddagger}$ & $1697(35 \%)$ & $233(29 \%)^{\ddagger}$ & $891(33 \%)^{*}$ & $989(36 \%)$ \\
\hline LMWH & $213(17 \%)$ & $887(18 \%)$ & $142(17 \%)$ & $419(16 \%)^{\ddagger}$ & $539(20 \%)$ \\
\hline Mean LMWH (IU/kg/day) & $154 \pm 54^{*}$ & $146 \pm 46$ & $145 \pm 52$ & $146 \pm 45$ & $145 \pm 52$ \\
\hline LMWH < 100 IU/kg/day & $26(2.0 \%)$ & $101(2.0 \%)$ & $22(2.7 \%)^{*}$ & $63(2.4 \%)^{*}$ & $22(0.8 \%)$ \\
\hline
\end{tabular}

$A S T$ aspartate aminotransferase, $A L T$ alanine aminotransferase, $F I B-4$ Fibrosis liver index $4, I Q R$ interquartile range, $L M W H$ Low molecular weight heparin, $I U$ international units

Comparisons between patients: ${ }^{*} p<0.05 ;{ }^{\dagger} p<0.01 ;{ }^{\ddagger} p<0.001$

such patients had elevated liver enzymes at baseline, and one in every 7-8 (13\%) had a FIB-4 index score over 2.67 points (high probability of liver fibrosis). This finding is important since patients with elevated liver enzymes were at an increased risk for death during anticoagulation, and those with high probability for liver fibrosis were at an increased risk for major bleeding, even after adjusting by potential confounders. Besides, there was a linear association between FIB-4 levels and the risk for major bleeding. To our knowledge, this association between routine liver tests at baseline and outcome in patients with VTE has not been consistently reported before. Our findings are particularly relevant since we excluded VTE patients with previously known liver disorders, serum transaminases $>200 \mathrm{UI} / \mathrm{L}$, excessive alcohol consumption or cancer, seeking to avoid confounding factors. Moreover, we used the cut-off values of liver enzymes and FIB-4 according to previously published articles [25].

In this cohort, patients with elevated liver enzymes were significantly younger than those with normal levels. On the contrary, patients with elevated FIB-4 levels were older than those with normal levels. This result was not unexpected since the patient's age is one of the items of the FIB-4 index score. However, patients with elevated liver enzymes or high FIB-4 levels had worse outcomes in most age subgroups, particularly in those with higher rates of events, and the risks even persisted after adjusting for age on multivariable analysis. A limitation of the present study was the lack of events ( 11 deceased patients and 18 major bleeding events out of 2024 evaluated subjects) in the age subgroups under 65 years old, which was partially solved by multivariate analysis but might need a validation in younger populations.

Besides, the use of FIB-4 in the present study might represent a limitation if interpreted as a tool to assess liver fibrosis in patients, due to the low specificity of this marker in the elderly (CITA). Nevertheless, the objective of the present study was to evaluate the FIB-4 and elevated liver enzymes as a prognostic tool in a different scenario, such as the presentation of an acute thromboembolic event. FIB-4 has been previously demonstrated to have predictive value in the acute setting independent of age $[16,19,20]$. Our interpretation is that the evaluation of the liver status using FIB-4 might provide prognostic information in these patients, avoiding to convey that according to the results of our study, fibrosis is related to poor prognosis in these patients, which would have to be proven in further studies. Besides, results were adjusted by age to avoid an excessive weight of this variable in the final results.

Besides, the use of FIB-4 in the present study might represent a limitation if interpreted as a tool to assess liver fibrosis in patients, due to the lack of specificity of this marker in the elderly [26]. Nevertheless, the objective of the present study is to evaluate the FIB-4 and elevated 
Table 3 Uni- and multivariable analysis for mortality and for major bleeding

\begin{tabular}{|c|c|c|c|c|}
\hline & \multicolumn{2}{|c|}{ All-cause death $(n=168)$} & \multicolumn{2}{|c|}{ Major bleeding $(n=92)$} \\
\hline & Univariable & Multivariable & Univariable & Multivariable \\
\hline \multicolumn{5}{|l|}{ Demographics } \\
\hline Age, years & $1.09(1.08-1.11)^{\ddagger}$ & $1.07(1.05-1.09)^{\ddagger}$ & $1.04(1.02-1.05)^{\ddagger}$ & $1.02(1.01-1.04)^{*}$ \\
\hline Male sex & $0.70(0.52-0.96)^{*}$ & $1.43(1.02-2.01)^{*}$ & $0.51(0.33-0.79)^{\dagger}$ & $0.59(0.38-0.96)^{*}$ \\
\hline \multicolumn{5}{|l|}{ Initial VTE presentation } \\
\hline Isolated DVT & $0.58(0.37-0.90)^{*}$ & $0.94(0.59-1.51)$ & $0.54(0.29-1.03)$ & \\
\hline SBP levels $<100 \mathrm{mmHg}$ & $2.27(1.41-3.66)^{\ddagger}$ & $1.55(0.96-2.52)$ & $1.71(0.83-3.54)$ & \\
\hline \multicolumn{5}{|l|}{ Concomitant disorders } \\
\hline Gastroduodenal ulcer & $1.87(0.70-5.05)$ & - & $3.48(1.28-9.47)^{*}$ & $2.39(0.86-6.61)$ \\
\hline Recent major bleeding & $4.17(2.26-7.69)^{\ddagger}$ & - & $3.83(1.67-8.77)^{\ddagger}$ & \\
\hline Chronic heart failure & $1.01(0.99-1.02)$ & - & $1.01(0.98-10.3)$ & \\
\hline Chronic lung disease & $1.16(0.70-1.91)$ & - & $1.29(0.72-2.31)$ & \\
\hline Diabetes mellitus & $0.99(0.99-1.01)$ & - & $0.98(0.96-1.01)$ & \\
\hline Prior ischemic stroke & $1.00(0.99-1.01)$ & - & $0.99(0.98-1.01)$ & \\
\hline Anemia & $2.96(2.20-4.01)^{\frac{\hbar}{5}}$ & - & $3.66(2.43-5.53)^{\frac{1}{5}}$ & \\
\hline Platelet count $\times 1000 / \mathrm{mm}^{3}$ & $0.99(0.99-1.00)$ & - & $1.00(0.99-1.00)$ & \\
\hline $\mathrm{CrCl}$ levels $<60 \mathrm{~mL} / \mathrm{min}$ & $3.84(2.70-5.48)^{\ddagger}$ & $1.20(0.78-1.85)$ & $2.05(1.34-3.14)^{\ddagger}$ & $0.72(0.42-1.23)$ \\
\hline No concomitant disorders & $0.24(0.16-0.36)^{\ddagger}$ & $0.47(0.31-0.70)^{\ddagger}$ & $0.46(0.30-0.73)^{\ddagger}$ & $0.70(0.45-1.12)$ \\
\hline \multicolumn{5}{|l|}{ Risk factors for VTE } \\
\hline Recent immobility & $4.27(3.16-5.78)^{\ddagger}$ & $2.67(1.95-3.67)^{\ddagger}$ & $1.77(1.15-2.74)^{\dagger}$ & $1.21(0.77-1.89)$ \\
\hline Unprovoked VTE & $0.50(0.37-0.69)^{\frac{\ddagger}{t}}$ & - & $0.89(0.59-1.34)$ & \\
\hline \multicolumn{5}{|l|}{ Bleeding risk assessment } \\
\hline RIETE score, per point & $1.75(1.58-1.94)^{\frac{1}{5}}$ & $1.24(1.09-1.41)^{\dagger}$ & $1.71(1.49-1.97)^{\ddagger}$ & $1.54(1.31-1.81)^{\ddagger}$ \\
\hline \multicolumn{5}{|l|}{ Liver status } \\
\hline Elevated liver enzymes & $1.11(0.77-1.59)$ & $1.58(1.10-2.28)^{*}$ & $1.14(0.70-1.86)$ & $1.39(0.85-2.27)$ \\
\hline FIB-4 index, per point & $1.33(1.24-1.43)^{\ddagger}$ & $1.11(1.01-1.23)^{*}$ & $1.32(1.19-1.48)^{\ddagger}$ & $1.22(1.07-1.39)^{\prime}$ \\
\hline FIB-4 index $>2.67$ points & $2.43(1.73-3.41)^{\ddagger}$ & $1.23(0.87-1.75)$ & $2.32(1.46-3.71)^{\ddagger}$ & $1.69(1.04-2.74)^{*}$ \\
\hline
\end{tabular}

Results are expressed as hazard ratio and $95 \%$ confidence intervals

Results in italics: elevated liver enzymes, FIB-4 index and FIB-4 score $>2.67$ were included in different multivariate models adjusted by age, sex, isolated DVT, SBP levels $<100 \mathrm{mmHg}$, absence of co-morbidity, $\mathrm{ClCr}$ clearance $<60 \mathrm{ml} / \mathrm{min}$ and Bleeding risk assessment

Mortality models: Harrel $\mathrm{C}$ test for mortality model without liver evaluation $=0.848$ elevated liver enzymes model $=0.851$, Harrel C test for FIB-4 model $=0.851$, Harrel $\mathrm{C}$ test for high risk fibrosis $=0.849$

Bleeding models: Harrel $\mathrm{C}$ test for bleeding model without liver evaluation $=0.728$ elevated liver enzymes $=0.729$; Harrel $\mathrm{C}$ test for FIB-4 model $=0.730$; Harrel $\mathrm{C}$ test for high risk of fibrosis $=0.730$

$V T E$ venous thromboembolism, $D V T$ deep vein thrombosis, $C r C l$ creatinine clearance, $A S T$ aspartate aminotransferase, $A L T$ alanine aminotransferase, $F I B-4$ Fibrosis liver index 4

Comparisons between patients: ${ }^{*} p<0.05 ;{ }^{\dagger} p<0.01 ;{ }^{\ddagger} p<0.001$ liver enzymes as a prognostic tool in a different scenario, which is the presentation of an acute thromboembolic event. FIB-4 has been previously demonstrated to have predictive value in the acute setting independently from age $[16,19,20]$. Our conclusion is that the evaluation of the liver status using FIB-4 might provide prognostic information in these patients, avoiding to convey that according to the results of our study, fibrosis is related to poor prognosis in these patients, which would have to be proven in further studies. Besides, results were adjusted by age to avoid an excessive weight of this variable in the final results.
The relationship between liver status and the thrombosis-bleeding balance has much been debated [27]. Unexpectedly, some patients with advanced liver diseases may have some degree of hypercoagulability, with a potential benefit for anticoagulant therapy. [28-31] These findings might be partly explained by a significant decrease on thrombomodulin-mediated inhibition of thrombin [32]. Nevertheless, the predisposition for bleeding in both acute and chronic liver diseases remains controversial, [33] and some experts suggested that the liver inflammation might be a potential predictor for bleeding [34]. In this context, the association between liver enzymes at VTE diagnosis and a higher risk 


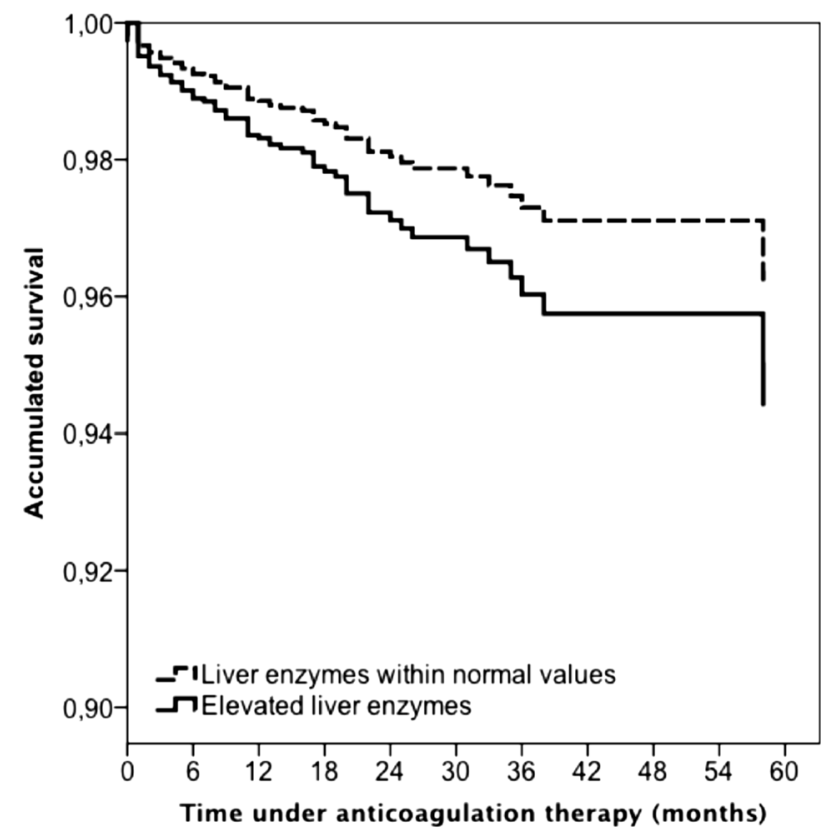

Fig. 2 Adjusted Cox regression analysis for all-cause mortality during anticoagulation, according to elevated vs. normal liver enzymes

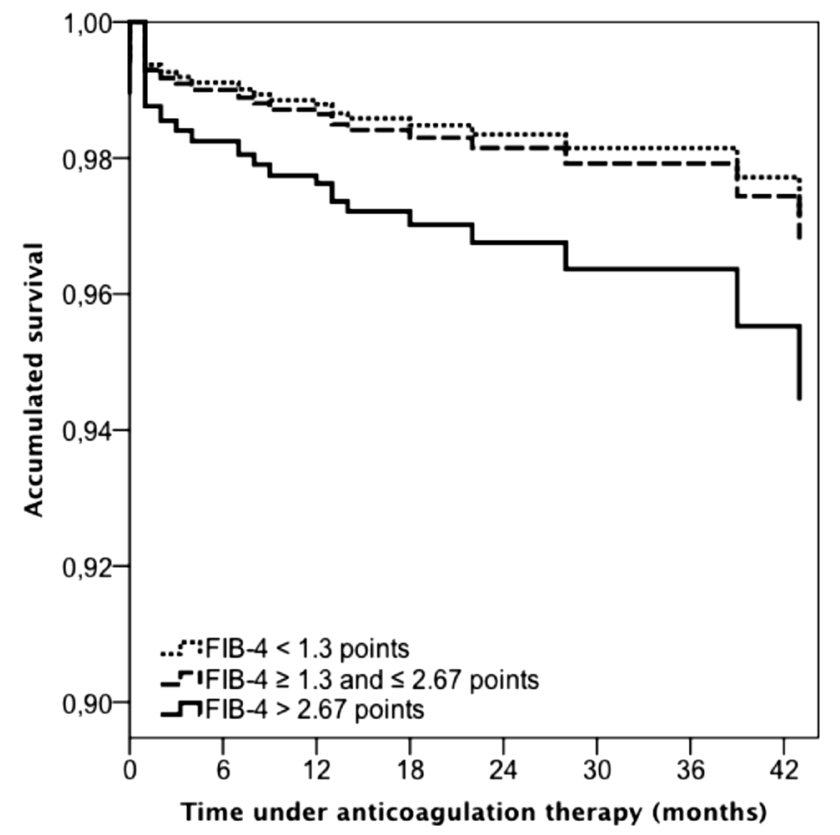

Fig. 3 Adjusted Cox regression analysis for major bleeding during anticoagulation according to risk for liver fibrosis

for bleeding or to die might help to establish the basis for an association between the thrombosis-bleeding balance and the liver status in patients with undetected hepatic disease.

Our study has a number of limitations that need to be addressed. First, RIETE provides insights into the natural history of VTE in an unselected patient population, in contrast to the rigorously controlled conditions of randomized clinical trials. It can, therefore, help to identify factors associated with worse outcomes, and provide feedback from real-world clinical situations which may be valuable when designing new clinical studies (hypothesis generating). Despite our efforts to control any bias from concomitant diseases and therapies, it is likely that we were unable to completely eliminate such bias.

A particular drawback could be the absence of registration of concomitant drug therapy of patients since some medications might be directly related to liver status, especially statins. Thus, the main illnesses that could lead to HMG-CoA reductase inhibitors (diabetes and heart disease) were tested and showed no differences in prognosis. Besides, all multivariate models were adjusted by the presence of co-morbidity which might be a proxy of drug prescription and could provide further bias control to the model. The incomplete record of the BMI values could also be considered a limitation of our study. In the RIETE registry recordings, height was not included as a mandatory value to fulfill. Thus, 1483 patients had not reported height, so BMI was unable to calculate. Although BMI did not affect the FIB-4 index results, statistically significant differences were found in BMI among patients with elevated and normal liver enzymes $(28.8 \pm 5.7$ vs $28.0 \pm 5.6$, respectively), while quantitative differences among groups were small. Although this variable was not included in the final mortality model due to significant reduction of statistical power, BMI seemed to be protective in the univariate mortality analysis, which is consistent with previously published reports [35]. In this context, as a protective factor (BMI) had a higher result in the group at risk (elevated liver enzymes) than in the control group (Normal liver enzymes), it could be hypothesized that if the statistical power was enough to evaluate BMI, the mortality prognostic capacity of elevated liver enzymes would be even greater.

The worse outcome in patients with elevated liver enzymes of FIB-4 levels may reflect pre-existing, unrecognized, disease processes, the coexistence of unrecognized liver disorders or the use of drugs. Moreover, the RIETE registry is focused on patients with VTE and contains many variables that may influence on their outcome, but only few variables to evaluate liver status. This study also has unique strengths including its large sample size which is considerably larger than other studies. In addition, registry data are audited for accuracy and completeness which provides highquality data for analysis.

\section{Conclusion}

The evaluation of liver enzymes or FIB-4 index at baseline in apparent liver disease-free patients with acute VTE may provide additional prognostic information concerning 
the risks for major bleeding or death during the course of anticoagulation.

Supplementary Information The online version contains supplementary material available at https://doi.org/10.1007/s11739-021-02858-x.

Acknowledgements We express our gratitude to Sanofi Spain, LEO PHARMA and ROVI for supporting this Registry with an unrestricted educational grant. We also thank the RIETE Registry Coordinating Center, S\&H Medical Science Service, for their quality control data, logistic and administrative support. MD Adarraga, J Aibar, J Alonso, C Amado, JI Arcelus, A Asuero, A Ballaz, R Barba, C Barbagelata, M Barrón, B Barrón-Andrés, A Blanco-Molina, F Beddar Chaib, E Botella, J Castro, L Chasco, J Criado, C de Ancos, J del Toro, P Demelo-Rodríguez, AM Díaz-Brasero, MC Díaz-Pedroche, JA DíazPeromingo, MV Di Campli, A Dubois-Silva, JC Escribano, F Espósito, AI Farfán-Sedano, C Fernández-Capitán, JL Fernández-Reyes, MA Fidalgo, K Flores, C Font, L Font, I Francisco, C Gabara, F GaleanoValle, MA García, F García-Bragado, M García de Herreros, RG de la Garza, C García-Díaz, A Gil-Díaz, C Gómez-Cuervo, E Grau, L Guirado, J Gutiérrez, L Hernández-Blasco, L Jara-Palomares, MJ Jaras, D Jiménez, R Jiménez, C Jiménez-Alfaro, MD Joya, S LainezJusto, A Lalueza, A Latorre, J Lima, JL Lobo, L López-Jiménez, P López-Miguel, JJ López-Núñez, R López-Reyes, JB López-Sáez, A Lorenzo, O Madridano, A Maestre, PJ Marchena, M Martín del Pozo, F Martín-Martos, D Martínez-Urbistondo, C Mella, MI Mercado, J Moisés, M Monreal, A Muñoz-Blanco, JA Nieto, E Nofuentes-Pérez, MJ Núñez-Fernández, M Olid-Velilla, MC Olivares, J Osorio, S Otalora, R Otero, D Paredes, JM Pedrajas, JA Porras, J Portillo, I Redondo, C Rodríguez-Matute, V Rosa, P Ruiz-Artacho, J Ruiz-Ruiz, G Salgueiro, R Sánchez-Martínez, JF Sánchez-Muñoz-Torrero, T Sancho, S Soler, B Suárez-Rodríguez, JM Suriñach, MI Torres, A Torres-Sánchez, C Tolosa, J Trujillo-Santos, F Uresandi, B Valero, R Valle, JF Varona, L Vela, JR Vela, G Vidal, A Villalobos, P Villares, C Zamora, C Ay, S Nopp, I Pabinger, MM Engelen, T Vanassche, P Verhamme, J Hirmerova, R Malý, S Accassat, N Ait Abdallah, L Bertoletti, A BuraRiviere, J Catella, F Couturaud, B Crichi, P Debourdeau, O Espitia, D Farge-Bancel, C Grange, H Helfer, K Lacut, R Le Mao, I Mahé , P Morange, F Moustafa, G Poenou, G Sarlon-Bartoli, P Suchon, I Quere, S Schellong, A Braester, B Brenner, G Kenet, I Tzoran, M Basaglia, F Bilora, C Bortoluzzi, B Brandolin, M Ciammaichella, A De Angelis, P Di Micco, E Imbalzano, S Merla, R Pesavento, P Prandoni, C Siniscalchi, A Tufano A, A Visonà, N Vo Hong, B Zalunardo, Y Nishimoto, Y Sato, K Make, A Skride, S Strautmane, S Fonseca, F Martins, J Meireles, M Bosevski, H Bounameaux, L Mazzolai, JA Caprini, HM Bui.

Author contributions DMU, PVF, RGDG, MM contributed in the study design, patient recruitment, investigation, statistical analysis, writing of the original manuscript, review of the original manuscript. CF, SS, JJLN, AGD, MCDP, JH contributed in the study design, patient recruitment, investigation and reviewing of the original manuscript.

Funding No funding was received to perform the present investigation. The authors declare no conflict of interest. The study was performed with an Ethics Board Approval. ClinicalTrials.gov identifier, NCT02832245.

\section{Declarations}

Conflict of interest All the authors Diego Martínez-Urbistondo, Rocío $\mathrm{G}$ de la Garza, Paula Villares-Fernández, Carme Font, Sebastian Schellong, Juan José López-Núñez Aída Gil-Díaz, María del Carmen Díaz-Pedroche, Jana Hirmerova and Manuel Monreal declare no conflicts of interest.
Statements on human and animal rights All procedures were approved by the Fundación para el Estudio de la Enfermedad Tromboembólica en España (FUENTE), Fundación Española de Medicina Interna (FEMI) and Sociedad Española de Neumología y Cirugía Torácica (SEPAR).

Informed consent All participants provided informed consent prior to participation.

\section{References}

1. Younossi ZM, Stepanova M, Afendy M, Fang Y, Younossi Y, Mir H, Srishord M (2011) Changes in the prevalence of the most common causes of chronic liver diseases in the United States from 1988 to 2008. Clin Gastroenterol Hepatol 9(6):524-530

2. Friedman SL (2010) Evolving challenges in hepatic fibrosis. Nat Rev Gastroenterol Hepatol 7(8):425-436

3. Ruhl CE, Everhart JE (2015) Fatty liver indices in the multiethnic United States National Health and Nutrition Examination Survey. Aliment Pharmacol Ther 41(1):65-76

4. Motamed N, Rabiee B, Farahani B, Khonsari MR, Kheyri Z et al (2017) Association of liver enzymes with 10-year cardiovascular disease risk: a population-based study. Hepat Mon 17(1):e43901

5. Kunutsor SK, Apekey TA, Khan H (2014) Liver enzymes and risk of cardiovascular disease in the general population: a meta-analysis of prospective cohort studies. Atherosclerosis 236(1):7-17

6. Park EO, Bae EJ, Park BH, Chae SW (2020) The associations between liver enzymes and cardiovascular risk factors in adults with mild dyslipidemia. J Clin Med 9(4):1147

7. Choi KM, Han K, Park S, Chung HS, Kim NH, Yoo HJ, Seo JA, Kim SG, Kim NH, Baik SH, Park YG, Kim SM (2018) Implication of liver enzymes on incident cardiovascular diseases and mortality: a nationwide population-based cohort study. Sci Rep $8(1): 3764$

8. Katzke V, Johnson T, Sookthai D, Hüsing A, Kühn T, Kaaks R (2020) Circulating liver enzymes and risks of chronic diseases and mortality in the prospective EPIC-Heidelberg case-cohort study. BMJ Open 10(3):e033532

9. Folsom AR, Lutsey PL, Roetker NS, Rosamond WD, Lazo M, Heckbert SR, Basu S, Cushman M, Selvin E (2014) Elevated hepatic enzymes and incidence of venous thromboembolism: a prospective study. Ann Epidemiol 24(11):817-821.e2

10. Dulai PS, Singh S, Patel J et al (2017) Increased risk of mortality by fibrosis stage in nonalcoholic fatty liver disease: systematic review and meta-analysis. Hepatology 65(5):1557-1565

11. Schonmann Y, Yeshua H, Bentov I, Zelber-Sagi S (2021) Liver fibrosis marker is an independent predictor of cardiovascular morbidity and mortality in the general population. Dig Liver Dis 53(1):79-85

12. Schuppan D, Surabattula R, Wang XY (2018) Determinants of fibrosis progression and regression in NASH. J Hepatol 68(2):238-250

13. Hagström H, Nasr P, Ekstedt M, Hammar U, Stål P, Hultcrantz R, Kechagias S (2017) Fibrosis stage but not NASH predicts mortality and time to development of severe liver disease in biopsyproven NAFLD. J Hepatol 67(6):1265-1273

14. Martinez-Urbistondo D, Suarez Del Villar R, Argemí J, Daimiel L, Ramos-López O, San-Cristobal R, Villares P, Martinez JA (2020) Antioxidant lifestyle, co-morbidities and quality of life empowerment concerning liver fibrosis. Antioxidants (Basel) 9(11): 1125

15. Kang MK, Park JG, Kim MC (2020) Association between atrial fibrillation and advanced liver fibrosis in patients with non-alcoholic fatty liver disease. Yonsei Med J 61(10):860-867 
16. Cao YX, Zhang M, Zhang HW, Jin JL, Liu HH, Zhang Y, Guo YL, Wu NQ, Zhu CG, Xu RX, Gao Y, Dong Q, Sun J, Li JJ (2021) Impact of liver fibrosis score on prognosis in patients with previous myocardial infarction: a prospective cohort study. Liver Int. https://doi.org/10.1111/liv.14780

17. Chun HS, Lee JS, Lee HW, Kim BK, Park JY, Kim DY, Ahn SH, Lee YH, Kim YD, Kim SU (2020) Association between the severity of liver fibrosis and cardiovascular outcomes in patients with type 2 diabetes. J Gastroenterol Hepatol. https://doi.org/10.1111/ jgh. 15387

18. Lee J, Kim HS, Cho YK, Kim EH, Lee MJ, Bae IY, Jung CH, Park JY, Kim HK, Lee WJ (2020) Association between noninvasive assessment of liver fibrosis and coronary artery calcification progression in patients with nonalcoholic fatty liver disease. Sci Rep 10(1):18323

19. Zhu X, Hu X, Qin X, Pan J, Zhou W (2020) An elevated Fibrosis-4 score is associated with poor clinical outcomes in patients with sepsis: an observational cohort study. Pol Arch Intern Med 130(12):1064-1073

20. Li Y, Regan J, Fajnzylber J, Coxen K, Corry H, Wong C, Rosenthal A, Atyeo C, Fischinger S, Gillespie E, Chishti R, Baden L, Yu XG, Alter G, Kim A, Li JZ (2020) Liver fibrosis index FIB-4 is associated with mortality in COVID-19. Hepatol Commun 5(3):434-445

21. Yuan CX, Ruan YT, Zeng YY, Cheng HR, Cheng QQ, Chen YB, He WL, Huang GQ, He JC (2020) Liver fibrosis is associated with hemorrhagic transformation in patients with acute ischemic stroke. Front Neurol 11:867

22. Bikdeli B, Jimenez D, Hawkins M, Ortíz S, Prandoni P, Brenner B, Decousus H, Masoudi FA, Trujillo-Santos J, Krumholz HM, Monreal M (2018) Rationale, design and methodology of the computerized registry of patients with venous thromboembolism (RIETE). Thromb Haemost 118(1):214-224

23. Babor TF, Higgins-Biddle J, Saunders J, Monteiro MG (2001) AUDIT: the alcohol use disorders identification test, Guidelines for use in Primary Care, 2nd edn. World Health Organization, Geneva, $p$

24. Vallet-Pichard A, Mallet V, Nalpas B, Verkarre V, Nalpas A, Dhalluin-Venier V, Fontaine H, Pol S (2007) FIB-4: an inexpensive and accurate marker of fibrosis in HCV infection. Comparison with liver biopsy and fibrotest. Hepatology. 46(1):32

25. Shah AG, Lydecker A, Murray K, Neuschwander-Tetri BA, Contos MJ, Sanyal AJ (2009) Comparison of noninvasive markers of fibrosis in patients with nonalcoholic fatty liver disease. Clin Gastroenterol Hepatol 7(10):1104-1112

26. van Kleef LA, Sonneveld MJ, de Man RA, de Knegt RJ (2021) Poor performance of FIB-4 in elderly individuals at risk for chronic liver disease-implications for the clinical utility of the EASL NIT guideline. J Hepatol S0168-8278(21):02012-02022. https://doi.org/10.1016/j.jhep.2021.08.017

27. Northup PG, Caldwell SH (2013) Coagulation in liver disease: a guide for the clinician. Clin Gastroenterol Hepatol
11(9):1064-1074. https://doi.org/10.1016/j.cgh.2013.02.026 (Epub 2013 Mar 16 PMID: 23506859)

28. Ambrosino P, Tarantino L, Di Minno G, Paternoster M, Graziano V, Petitto M, Nasto A, Di Minno MN (2017) The risk of venous thromboembolism in patients with cirrhosis. A systematic review and meta-analysis. Thromb Haemost 117(1):139-148. https:// doi.org/10.1160/TH16-06-0450 (Epub 2016 Oct 20 PMID: 27761574)

29. Tripodi A, Mannucci PM (2011) The coagulopathy of chronic liver disease. N Engl J Med 365(2):147-156. https://doi.org/10. 1056/NEJMra1011170 (PMID: 21751907)

30. Leonardi F, Maria N, Villa E (2017) Anticoagulation in cirrhosis: a new paradigm? Clin Mol Hepatol 23(1):13-21. https://doi.org/ 10.3350/cmh.2016.0110 (Epub 2017 Mar 14. PMID: 28288507; PMCID: PMC5381832)

31. Noronha Ferreira C, Marinho RT, Cortez-Pinto H, Ferreira P, Dias MS, Vasconcelos M, Alexandrino P, Serejo F, Pedro AJ, Gonçalves A, Palma S, Leite I, Reis D, Damião F, Valente A, Xavier Brito L, Baldaia C, Fatela N, Ramalho F, Velosa J (2019) Incidence, predictive factors and clinical significance of development of portal vein thrombosis in cirrhosis: a prospective study. Liver Int 39(8):1459-1467. https://doi.org/10.1111/liv.14121 (Epub 2019 May 15 PMID: 31021512)

32. Zermatten MG, Fraga M, Calderara DB, Aliotta A, Moradpour D, Alberio L (2020) Biomarkers of liver dysfunction correlate with a prothrombotic and not with a prohaemorrhagic profile in patients with cirrhosis. JHEP Rep 2(4):100120. https://doi.org/10.1016/j. jhepr.2020.100120.PMID:32715285;PMCID:PMC7369360

33. Lisman T, Kamphuisen PW, Northup PG, Porte RJ (2013) Established and new-generation antithrombotic drugs in patients with cirrhosis-possibilities and caveats. J Hepatol 59(2):358-366. https://doi.org/10.1016/j.jhep.2013.03.027 (Epub 2013 Mar 30 PMID: 23548197)

34. Stotts MJ, Lisman T, Intagliata NM (2020) The spectrum of disease severity in cirrhosis and its implications for hemostasis. Semin Thromb Hemost 46(6):716-723. https://doi.org/10.1055/s0040-1715449 (Epub 2020 Aug 20 PMID: 32820482)

35. Giorgi-Pierfranceschi M, López-Núñez JJ, Monreal M, Cattabiani C, Lodigiani C, Di Micco P, Bikdeli B, Braester A, Soler S, Dentali F (2020) RIETE researchers. Morbid obesity and mortality in patients with VTE: findings from real-life clinical practice. Chest. 157(6):1617-1625. https://doi.org/10.1016/j.chest.2019.12. 040 (Epub 2020 Jan 29)

Publisher's Note Springer Nature remains neutral with regard to jurisdictional claims in published maps and institutional affiliations. 